Reprod. Nutr. Dévelop., 1987, 27 (4), 859-863.

\title{
Repeated superovulation and surgical recovery of embryos in the ewe
}

\author{
Suzanne TORRĖS, Claude SEVELLEC
}

Station de Physiologie animale, I.N.R.A. 78350 Jouy-en-Josas, France.

Summary. Repeated superovulation using three treatments of pFSH at intervals of 45 to 55 days during the same breeding season was carried out in 18 Préalpes ewes.

The embryos were recovered by surgery after the first two treatments and by slaughter after the last one at Day 6 . Three lots of control ewes $(n=5$ or 6 ) receiving the same superovulation treatment were slaughtered respectively at the same time.

The first and third repeated superovulation treatments gave averages of $5.2 \pm 0.6$ and $4.5 \pm 0.6$ corpora lutea. The second one gave $3.4 \pm 0.4$ corpora lutea, which was significantly lower than with treatments 1 and 3, but adhesions did not permit a perfect view of the whole surface of the ovaries.

Recovery rates decreased regularly with repeated collection $188.2,52$ and $24 \%$, respectively). The proportion of embryos at the morula/blastocyst stage also decreased from 86 and $93 \%$ to $6.7 \%$ at the third treatment.

The development of post-surgical lesions probably caused variations in the apparent rate of ovulation and a decrease of egg recovery and fertilization rates.

In control ewes the mean level of superovulation did not vary significantly during the breeding season and embryonic development was normal when checked at slaughter.

Repeated superovulation using pFSH is worthwile only if the eggs are recovered by perfusion with an appropriate catheter (introduced into the uterus by laparoscopy) instead of by surgery.

\section{Introduction.}

The development of embryo transfer in sheep demands the production of a large number of embryos. In a previous study (Torrès et al., 1987), we estimated that one donor ewe supplies an average of about 6 transferable embryos after pFSH treatment. It seemed interesting to know if repetition of the treatment during the breeding season could increase the number of embryos available per ewe and per year.

Cows superovulated with pregnant mare's serum gonadotropin (PMSG) show a substantial decline in ovarian response at a second treatment given 7 to 9 weeks after the first (Saumande and Chupin, 1977). As treatment with porcine FSH and PMSG in goats has shown a significantly better superovulatory response 
with FSH (Trounson, 1983), we used pFSH to determine how many embryos could be obtained after three superovulatory treatments followed each time by surgical recovery.

\section{Material and methods.}

The experiment was carried out in 12 to 15-month old Prealpes ewes and over two mating seasons (1985 and 1986). At the end of August, 18 ewes were given the first superovulatory treatment. $\mathrm{FSH}$-enriched pig pituitary extracts (CY1295, Y. Combarnous, I.N.R.A., Nouzilly, France) were used.

Progestagen-impregnated pessaries $(40 \mathrm{mg}$ of Cronolone, SC 9880, Searle, France) were inserted into the ewes and withdrawn 14 days later. Intramuscular injections at 12-hour intervals of decreasing doses of pFSH $(6,5,3,2 \mathrm{mg})$ started $24 \mathrm{~h}$ before pessary withdrawal (Cognié et al., 1985). With the last two injections of $\mathrm{pFSH}, 60$ and $90 \mu \mathrm{g}$ of $\mathrm{pLH}$, respectively, were added. Heat appeared regularly $24 \mathrm{~h}$ after sponge withdrawal ; the ewes were mated 12 and $24 \mathrm{~h}$ after the onset of oestrus.

The experimental ewes were given the same treatment three times at $50 \pm 5$ day intervals (E1, E2, E3). The embryos were recovered surgically after the first two treatments and post mortem at Day 6 after the last one. Three control lots $(\mathrm{C} 1, \mathrm{C} 2, \mathrm{C} 3)$ were given the same treatment synchronously with E1, E2 and E3, respectively. These ewes were slaughtered on D6 and their ovulation rates permitted us to determine any changes during the breeding season.

At the time of embryo recovery, the corpora lutea (CL) were counted and the morphological state of the eggs or embryos was observed.

\section{Results.}

There was no difference between the experiments of autumn 1985 and those of autumn 1986 as to number of $C L$, number of eggs recovered and stage of development, and therefore the two series of results were pooled for analysis.

Superovulation. - In spite of perfusion of both uterine horns, one experimental ewe remained pregnant and therefore only 17 ewes were available for the second treatment. Two had numerous adhesions and so did not receive the third superovulation treatment. The multiple adhesions observed were:

- uterine horns with oviducts and ovaries,

- adherent tag to another part of the same uterine horn,

- tags consisting of only a few strands of fibrin and easily broken down.

A comparison of the mean number of ovulations between treatments showed a decrease $(P<0.005)$ at the second treatment (table 1).

The ovulation rate of the three control lots (table 2) did not vary during the breeding season. When compared to the experimental ewes, the only difference $(P<0.01)$ found was between the second treatment (E2) and the second lot (C2). 
TABLE 1

Experimental ewes.

\begin{tabular}{lccc}
\hline & Treatment 1 & Treatment 2 & Treatment 3 \\
\hline $\begin{array}{l}\text { No. of ewes } \\
\text { Mean no. of corpora lutea } \pm \mathrm{SE}\end{array}$ & 18 & 17 & 15 \\
$\begin{array}{l}\text { Mean no. of embryos recovered } \\
\text { \% embryos recovered }\end{array}$ & $5.2 \pm 0.6{ }^{* * *}$ & $3.4 \pm 0.4{ }^{* * *}$ & $4.5 \pm 0.6$ \\
$\begin{array}{l}\text { corpora lutea } \\
\begin{array}{l}\text { Mean no. of morulae/blastocysts } \\
\text { \% morulae/blastocysts }\end{array}\end{array}$ & $4.5 \pm 0.6$ & $1.8 \pm 0.4$ & $1.15 \pm 0.3$ \\
embryos recovered & $48.2 \%$ & $52 \%$ & $24 \%$ \\
\hline
\end{tabular}

*** : Highly significant ; $P<0.005$.

TABLE 2

Control ewes.

\begin{tabular}{lccc}
\hline & Treatment 1 & Treatment 2 & Treatment 3 \\
\hline $\begin{array}{l}\text { No. of ewes } \\
\text { Mean no. of corpora lutea } \times \mathrm{SE}\end{array}$ & 6 & 5 & 5 \\
$\begin{array}{l}\text { Mean no. of embryos recovered } \pm \mathrm{SE} \\
\text { \% embryos recovered }\end{array}$ & $3.3 \pm 1.6$ & $4.8 \pm 1.2$ & $5.4 \pm 1.3$ \\
$\begin{array}{l}\text { corpora lutea } \\
\text { Mean no. of morulae/blastocysts }\end{array}$ & $83 \%$ & $4.3 \pm 0.7$ & $4.2 \pm 1.5$ \\
$\%$ morulae/blastocysts & $2.6 \pm 0.95$ & $37.5 \%$ & $78 \%$ \\
embryos recovered & $65 \%$ & $71 \%$ & $4.2 \pm 1.5$ \\
\hline
\end{tabular}

Recovered eggs and embryos. - The first surgical recovery of embryos was compared to results obtained after slaughter (E1 vs C1). The difference was not significant.

At the second surgical recovery, $52 \%$ of the eggs were collected in the E2 group compared to $88 \%$ in the E1 group $(\mathrm{P}<0.01)$ and $87.5 \%$ in the $\mathrm{C} 2$ lot. The drop in recovery rate was even more evident at the third recovery $124 \%$; $\mathrm{P}<0.005)$.

Developed embryos. - A certain proportion of these embryos developed normally and reached the morula/blastocyst stage at D6.

The proportion of normally developed embryos was especially low in the E3 group. Many unfertilized eggs were found, which would explain the difference between the mean of 1.15 eggs and 0.08 morula recovered per ewe (table 1 ); we found 4 ewes with 9 unfertilized eggs and 2 with 4 eggs showing retarded development. These ewes had extensive adhesions.

In control ewes (table 2), the mean number of morulae/blastocysts per ewe did not vary between September and December.

\section{Discussion.}

The level of superovulation obtained in ewe-lambs was lower than that of older sheep. Cognié et al. (1985) and Heyman et al. (1987) in similar conditions obtained a mean of 8 to $10 \mathrm{CL}$ in multiparous ewes. 
All the ewes treated in the present study came on heat and ovulated. Ovulation rate seemed to decrease at the second treatment but augmented again at the third treatment. These results contrast with those of Fukui et al. (1985) who did not note any drop in ovulation rate with treatment intervals of 56 to 71 days. However, those authors had to discard some ewes during treatment due to the development of adhesions in the genital tract. The drop in ovulation rate, observed at the second treatment in our study, could be due to the difficulty in seeing the whole surface of the ovaries. On the other hand, slaughtering the ewes after the third treatment did permit dissection and precise evaluation of the ovulation rates.

The results of repeated pFSH treatment did not vary; this is not the case with PMSG which seems to initiate a refractory state, especially in cattle (Saumande and Chupin, 1977) and sheep (McKelvey et al., 1986).

Repeated surgical recovery caused the development of adhesions in some ewes and thus hindered capture of the oocytes. However, the increased number of unfertilized eggs at the third treatment indicates that sperm transport might also be impaired.

It seems necessary in repeated superovulation treatments to recover the embryos by perfusing the uterine horns with a catheter adapted for laparoscopy instead of using surgery (McKelvey et al., 1986).

Reçu en février 1987.

Accepté en avril 1987

Résumé. Superovulations répétées et récupération chirurgicale des embryons chez la brebis.

Trois traitements de superovulation avec une préparation de $\mathrm{pFSH}$, à des intervalles de 45 à 55 jours au cours de la même saison sexuelle ont été réalisés chez 18 brebis Préalpes. A chaque traitement était associé un lot témoin ( $n=5$ à 6 ).

Les traitements répétés ont été suivis de récupération chirurgicale des embryons pour les deux premiers et d'abattage à $\mathrm{J} 6$ pour le dernier. Les brebis témoins ont reçu simultanément le même traitement de superovulation, mais ont été sacrifiées pour la collecte des embryons, également à $\mathrm{J} 6$.

Le nombre de corps jaunes est plus faible $(3,4 \pm 0,4)$ après le second traitement, qu'après les premier $(5,2 \pm 0,6)$ et troisième $(4,5 \pm 0,6)$, mais les adhérences qui se développent après les récupérations chirurgicales ne permettent pas de voir la totalité de la surface des ovaires.

Les taux de récupération diminuent régulièrement avec la répétition des traitements (respectivement $88,2,52$ et $24 \%$ ). La proportion d'embryons au stade morula/blastocyste décroît de 86 et $93 \%$ à $6,7 \%$ pour le troisième traitement.

Le développement des adhérences post-chirurgicales est vraisemblablement responsable des variations des taux de superovulation observés, de récupération des œufs et de fécondation.

Chez les brebis témoins, la moyenne de superovulation ne subit pas de modifications sensibles au cours de la saison sexuelle et les développements embryonnaires vérifiés après abattage des brebis à $\mathrm{J} 6$ sont normaux.

La superovulation répétée avec pFSH ne peut être utilisée avec profit que si on remplace la récupération chirurgicale par une perfusion à l'aide d'une sonde utérine adaptée et introduite par laparoscopie. 


\section{References}

COGNIÉ Y., CHUPIN D., SAUMANDE J., 1985. Comparison of two FSH treatment schedules to induce superovulation in ewes. Theriogenology, 23, 185.

FUKUI Y., KANO H., KOBAYASHI M., TETSURA M., ONO H., 1985. Response to repeated superovulation treatment in the ewe. Jap. J. anim. Reprod., 31, 155-157.

HEYMAN Y., VINCENT C., GARNIER V., COGNIE Y., 1987. Transfer of frozen-thauwed embryos in sheep. Vet. Rec., 120, 83-85.

McKELVEY W. A. C., ROBINSON J. J., AITKEN R. P., ROBERTSON T. S., 1986. Repeated recoveries of embryos from ewes by laparoscopy. Theriogenology, 25, 855-865.

SAUMANDE J., CHUPIN D., 1977. Superovulation : a limit to egg transfer in cattle. Theriogenology, 7, 141-149.

TORRĖS S., COGNIÉ Y., COLAS G., 1987. Transfer of superovulated sheep embryos. Theriogenology, 22, 407-419.

TROUNSON A., 1983. Comparative embryo transfer in Australia. Theriogenology, 19, 17-29. 